\title{
The Influences of Good Governance on Trust in Government: Case of Cambodia
}

\author{
CHHUM KUNTHEA \\ PhD Student \\ College of Public Administration, Huazhong University of Science and Technology, China
}

\begin{abstract}
Good governance is very important factor to build the citizens 'trust in government to provide the public service in each country. The dimensions of good government are rule of law, transparency, responsiveness, participation, equity, effectiveness and efficiency, accountability, and Consensus Oriented in the exercise of political, economic and administrative authority (Punyaratabandhu, 2004).This paper is to illustrate examined some factors of good governance (rule of law, transparency, accountability, responsiveness and equity and inclusiveness ) which influence on citizens' trust for serving public sector in Cambodia. This paper is participated with 400 respondents who were citizens (service recipients) participated in this study. The correlations and regression methods were employed in the IBM SPSS v.20. The study employed both online and face to face survey by which the determinants were examined in SPSS. The questionnaires were focused on in Battambang province.The majority of responses of participants were indicated that the determinants have the result as the following; Pearson's correlation is indicated rule of law, transparency, accountability, responsibility, and equity and inclusiveness has strong relationship with citizens' trust. Whereas, linear regression show that all direct effect to citizens' trust as the value $\mathrm{H} 1(\beta=-.343$ with $\mathrm{t}=2.54$ with sig. $=.011), \mathrm{H} 2(\beta=.310$ with $\mathrm{t}=3.924$ with sig. $=.000), \mathrm{H} 3(\beta=2.26$ with $\mathrm{t}$ $=11.94$ with sig. $=.000), \mathrm{H} 4(\beta=-2.18$ with $\mathrm{t}=-12.80$ with sig. $=.000), \mathrm{H} 5(\beta=.826$ with $\mathrm{t}=12.33$ with sig. $=.000$ ). Regarding to rule of significant, it is seen that all determinants are the strongly predicting predicted variable which is highest strongly positive influenced and linear regression the $\mathrm{H} 1$ (rule of law p-value $=.011$ ) is rejected.

DOI: $10.7176 / \mathrm{PPAR} / 10-11-08$
\end{abstract}

Publication date: November $30^{\text {th }} 2020$

\section{Introduction}

This research sites related to conception of good governance and the citizens' trust. Moreover, this includes the roles of government in the public organization to improve citizen trust and good governance in Cambodia. Citizens' trust and good governance have been generally viewed as closely interconnected. One of the most revolving questions in citizens' mind is "Whom should I be wary of if not the government who wields great power with great temptations to abuse it" (Bentham, James, Blamires, \& Pease-Watkin, 1999). Trust is considered one of the most crucial components for the legitimacy and sustainability of any political systems (Blind, 2007). According to the analysis of trust and government, it may focus on two quite distinct causal issues; citizen trust in other citizens in part of governmental institution and the citizen trust in government itself (Hardin, 1999).

"Good governance," a term that came into vogue in the 1990s with the World Bank leading the charge, has assumed the status of a mantra for donor agencies as well as donor countries for conditioning aid upon the performance of the recipient government. This is intended to ensure that the development assistance is used effectively (Nanda, 2006).The rationale of good governance is related to, combating corruption, nepotism, bureaucracy, and mismanagement and transparency, accountability, and proper procedures, aid would be effectively used to achieve the objective of reducing poverty (Doornbos, 1995).

For Cambodia, Good governance seems to be high on the agenda of the Royal Government of Cambodia and there have been numerous initiatives endorsed by the Government. These were explicitly designed to respond to the needs of citizens and to introduce mechanisms that ensure better governance, better public services, and more citizen participation (Babovic \& Vukovic, 2014).

In the implementation of Good Governance of Cambodia, the Royal Government of Cambodia (RGC) mainly focuses on only four reform areas: (1) judicial and legal reform; (2) public administration reform including decentralization and de-concentration; (3) anti-corruption reform; and (4) reform of the Royal Cambodian Armed Forces (Period 2004-2008; 2008-2013; 2013-2018) (Kevreaksmey, Bing, Ratanak, \& Keosambath, 2015).

Although the Royal Government of Cambodia has reformed the judicial and legal reform; the public administration reform including decentralization and de-concentration; the anti-corruption reform, it is still low level of good governance. This causes low level of citizens 'trust in government. According to the World Governance Indicator in 2018, It has also evaluated the Cambodia with low score of governance. There are six dimensions to assess the governance in the world. These are the voice and accountability, the political stability and absence of violence/terrorism, government effectiveness, regulatory quality, rule of law, and control of corruption. The score has been ranking by $-2.5=$ week and $2.5=$ strong presented the governance performance. The percentile ranking all among the countries is $0=$ lowest and $100=$ highest. The governance of Cambodia has 
been provided as the following table score (Bank, 2018)

Table 1: Governance Performance in Cambodia

Governance Performance

Voice and accountability

Score Ranking (-2.5 to 2.5$)$

Political Stability and Absent of

Violence $-1.16$

Percentile Ranking (0 to 100 ) $15 \%$

Government Effectiveness $\quad-0.66$

$52 \%$

Regulatory Quality

0.17

$15.38 \%$

$-0.66$

$32.12 \%$

Rule of law

$13.46 \%$

Control of Corruption

$-1.06$

$8.65 \%$

\section{Literature Review}

\subsection{Concept of Good Governance}

Related to the theory of good governance, the Royal Government of Cambodia (RGC) has developed nine characteristic dimensions. These characteristics are rule of law, transparency, responsiveness, participation, equity, effectiveness and efficiency, accountability, agreement and Consensus Oriented (Cambodia, 2010). The United Nations have determined eight dimensions for good governance which are rule of law, transparency, responsiveness, participation, equity, effectiveness and efficiency, accountability, and Consensus Oriented .The following figure is brief characteristics to identify the good governance (Punyaratabandhu, 2004).

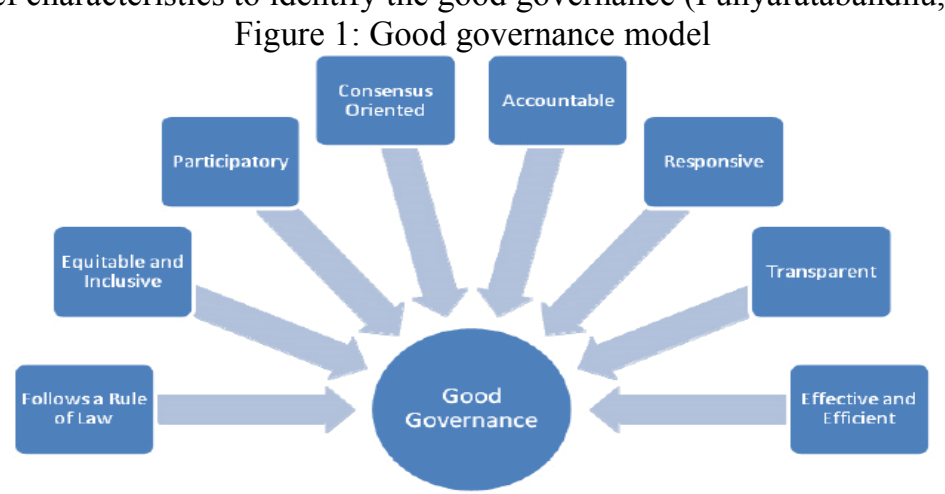

Figure 1: Good Governance Dimension by United Nation

Rule of law: Good governance requires fair legal frameworks that are enforced impartially. It also requires full protection of human rights, particularly those of minorities. Impartial enforcement of laws requires an independent (Yap Kioe Sheng, 2009). It is similar to the word "legitimacy" (Keping, 2018). It refers to the state or quality that social order and authority are voluntarily recognized and obeyed. It has no direct relevance to laws and regulations, and from the legal angle something legal is not necessarily legitimate. Only the authority and orders genuinely recognized by people within a specific group are legitimate in political science. The higher the degree of legitimacy is, the higher the level of good governance will be. The principal approach to achieving and improving legitimacy is to maximize the consensus and political identity shared by citizens. Therefore, good governance requires the relevant administrative bodies and administrators to manage various conflicts of interest among citizens and between them and the State to the maximum so as to obtain the citizens' maximum consent to and approval of their public administration activities (Keping, 2018). Transparency: It refers to the publicity of political information. All citizens are entitled to the information on State policies that are related to their own interests, including legislative activities, policy-making, legal provisions, policy enforcement, administrative budget, public expenditure and other relevant political information. Transparency requires that the aforementioned political information be duly communicated to citizens through various media vehicles so that they can participate in public policy-making and supervise the process of public administration in an effective manner. The higher the degree of transparency is, the higher the level of good governance will be (Keping, 2018). Responsiveness: It is closely associated with the aforementioned concept of accountability. In a sense, it is an extension of accountability. Essentially, it means that public administrators and administrative bodies must respond to the demands of citizens in a timely and responsible manner, and that it is forbidden to make delays without cause or leave any issue unresolved without response. When necessary, they should proactively solicit advice from citizens, explain their policies to them and answer their questions on a regular basis. The greater the level of responsiveness is, the higher the level of good governance will be (Keping, 2018). Participation: Both men and women are a key cornerstone of good governance. Participation could be either direct or through legitimate intermediate institutions or representatives. It is important to point out that representative democracy does not necessarily mean that the concerns of the most vulnerable in society would be taken into consideration in decision making. Participation needs to be informed and organized. This means freedom of association and expression on the one hand and an 
organized civil society on the other hand (Yap Kioe Sheng, 2009). Equity and inclusiveness: A society's wellbeing depends on ensuring that all its members feel that they have a stake in it and do not feel excluded from the mainstream of society. This requires all groups, but particularly the most vulnerable, have opportunities to improve or maintain their well-being (Yap Kioe Sheng, 2009). Effectiveness and efficiency: Good governance means that processes and institutions produce results that meet the needs of society while making the best use of resources at their disposal. The concept of efficiency in the context of good governance also covers the sustainable use of natural resources and the protection of the environment (Yap Kioe Sheng, 2009). Accountability: Accountability means holding every person accountable for his or her own behavior. In public administration, it refers in particular to the duties related to a certain position or institution and its corresponding obligations. Accountability means that administrators and administrative bodies must fulfill the functions and obligations of the positions they hold. If they fail to fulfill their bounden functions or duties, or if they do so in an inappropriate manner, their conduct constitutes dereliction of duty or lack of accountability. The more accountability the public, especially public officers and administrative bodies have, the higher the level of good governance will be. In this regard, good governance requires the employment of both law and ethics to enhance the accountability of individuals and institutions (Keping, 2018). Consensus Oriented: There are several actors and as many viewpoints in a given society. Good governance requires mediation of the different interests in society to reach a broad consensus in society on what is in the best interest of the whole community and how this can be achieved. It also requires a broad and long-term perspective on what is needed for sustainable human development and how to achieve the goals of such development. This can only result from an understanding of the historical, cultural and social contexts of a given society or community (Yap Kioe Sheng, 2009).

Government is a group of people who rule or run the administration of a country. In other words, it may be said that a government is the body of representatives that governs and controls the state at a given time. Government is the medium through which the power of the state is employed (Joshua, 2011), whereas, the governance is the act of governing or ruling. It is the set of rules and laws framed by the government that are to be implemented through the representatives of the state. Simply put, governance is what governments do (Joshua, 2011).

\subsection{Theoretical of Trust}

Trust was proposed by (Mayer, Davis, \& Schoorman, 1995) which is the willingness of a party to be vulnerable to the actions of another party based on the expectation that the other will perform a particular action important to the trust irrespective of the ability to monitor or control that other party. This definition of trust is applicable to a relationship with another identifiable party who is perceived to act and react with volition toward the trust receiver. According to (Mayer et al., 1995), he proposed the model of trustworthiness which has three determinants related to trust. These are ability, benevolence, and integrity which have been influenced on trust. Ability refers to the group of skills, competencies, and characteristics that enable a party to have influence within some specific domain. The domain of the ability is specific because the trustee may be highly competent in some technical area, affording that person trust on tasks related to that area. Benevolence is the extent to which a trustee is believed to want to do good to the trust receiver, aside from an egocentric profit motive. Benevolence suggests that the trustee has some specific attachment to the trust receiver. The integrity refers to the trust receivers' perception that the trustee adheres to a set of principles that the trust receiver finds acceptable. This model is illustrated as the following framework.

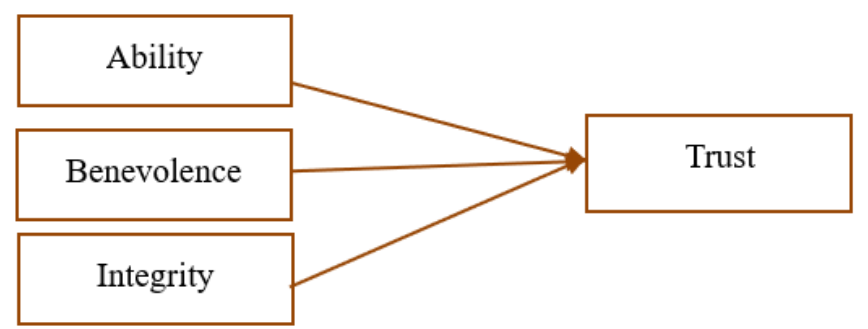

Figure 2: Determinant of Trust (Mayer et al., 1995)

Trust is a complex concept for which it is difficult to identify a commonly accepted definition but it is necessary to build trust in state and its agencies to establish the legitimacy of the state actions. If citizens trust the government, they are more likely to comply voluntarily with the directives and regulation (Caillier, 2010; RoseAckerman, 2001; Tsang, Burnett, Hills, \& Welford, 2009). Trusted public official enjoy more discretion and autonomy than the distrusted officials (Fard \& Rostamy, 2007). The concept of trust covers both politician and public officials. The factors that clearly influence trust are the keeping of promises, learning from mistakes, comments of family and friends about their services, the staff conduct towards customers, their interest in people's views, the qualities of leaders and the quality of leadership management (Salminen \& Ikola-Norrbacka, 2010). Trust as a central dimension consists of a number of interrelated elements and indicators. According to the 
definition of these two key terms, the citizen trust on government base on the good governance because they are close relationship to each other.

\subsection{Theoretical framework}

The Model theoretical framework determines how a given researcher formulates the research problem and how the researcher goes about investigating the problem, and what meaning she or he attaches to the data accruing from such an investigation (Imenda, 2014). Related to this definition, this study is not developed the new model of good governance or the citizens' trust in government institution. As the observing of good governance characteristics, the key terms of model are illustrated and explained as the following contexts.

This model is also investigated the citizens' trust in government practice on the principle of good government in Cambodia whether they trust or not. There are five determinant factors of good governance to measure the citizens' trust. These factors are rule of law, transparency, accountability, responsiveness and equity and inclusiveness.

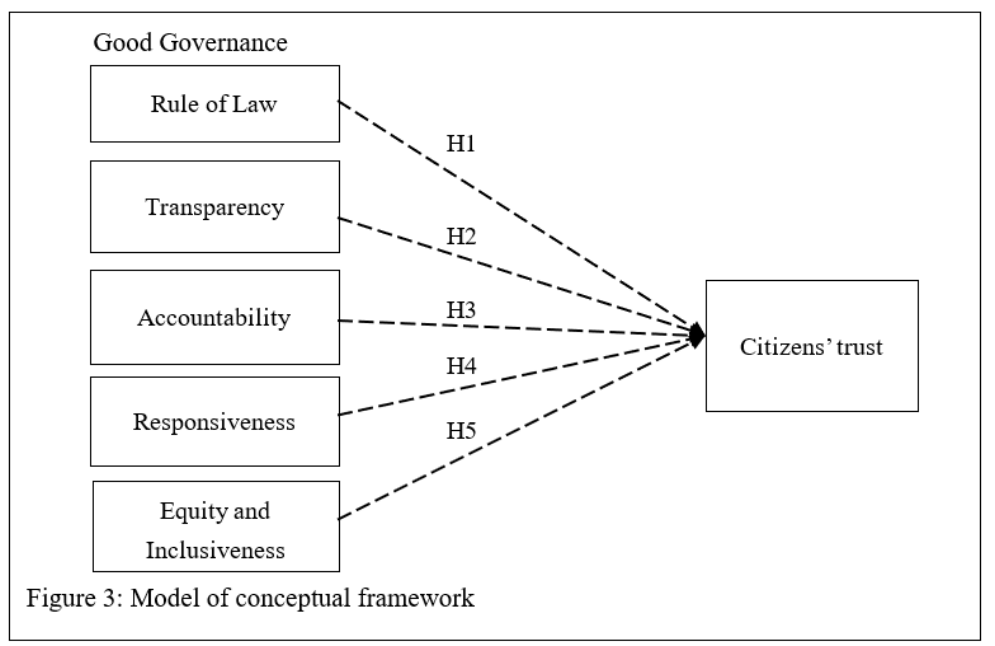

\subsection{Hypothesis Development}

Good governance: It is also very important factor to improve the citizens' trust government in both public and private factors. For example, World Bank Institute's Worldwide Governance Indicators purport to measure state aspects of state capacity (government effectiveness, regulatory quality, and stability and absence of violence, control of corruption)(Fukuyama, 2013). Governance is the action of governing an organization by using and regulating influence to direct and control the actions and affairs of management and others. It is the exclusive responsibility of the 'governing body', the person, or group accountable for the performance and conformance of the organization (Bourne, 2014).

Good governance has also important roles to improve the quality of works under the control of governmental organization. For instance, the definition of good governance was adapted that it is holding the balance between economic and social goals and between individual and communal goals. The governance framework is there to encourage the efficient use of resources and equally to require accountability for the stewardship of those resources. The aim is to align as nearly as possible the interests of individuals, the organization and society" (Bourne, 2014). On the other hand, the function of good governance was also found that good governance is offering a degree of protection against the failure and fraud (Cadbury, 2002).

As the above explaining reason, good governance has important roles to the citizens' trust in government in Cambodia. Therefore, the characteristics of good governance (rule of law, transparency, accountability, responsiveness, equity and inclusiveness) will be developed as the hypothesizes influenced on citizens' trust in government. These hypotheses will be illustrated as the following points.

Rule of law: It is very important roles to provide the citizens 'trust in governmental activities for Cambodia. The citizens will be motivated to take part the government project for social development if the rule of law is fair legal framework and enforce impartially. It is well known that societies highly fractionalized by ethnicity, religion or language face a number of serious challenges and the lower rule of law levels is more corruption being two of them (Gutmann \& Voigt, 2018). Therefore, this hypothesis needs to be investigated the relationship between rule of the citizens' trust as following statement.

H1: The high level of rule of law of government has a positive influenced on citizens' trust in government in Cambodia.

Transparency: It refers to proper and clarified information in administrative system in governmental organization. It is also vital factor to increase the citizens' trust in government in Cambodia. The concept of 
transparency involves the details of the service reasoning, and of other types of information management, involving sensible information, and/or possible consequences about the knowledge that the government is gaining of the user implicitly (Ananny \& Crawford, 2018). The degree of transparency is the extent to which an organization allows people to monitor its performance and participate in its policy decision-making (Burman, Albinsson, \& Hyatt, 2016).

In Cambodia, the term transparency is always criticized by the position party, civil society organization and as well as the citizens. It is also measured the relationship the citizens' trust in government. As the reason explaining, transparency will be developed in hypothesis as the following statement.

H2: The high level of transparency of government has a positive influenced on citizens' trust in government in Cambodia.

Accountability: In this study, it refers to the reliable work of government to use power fairly and independently for citizen. Accountability has a role in building and maintaining trust, and potentially a critical one (Hyndman \& McConville, 2018). It has been highlighted as a sine qua non to the building of trust in charities: accountability is necessary to promote public trust (Sloan, 2009). Therefore, accountability will be proposed to investigate the citizens' trust in government for Cambodia as the following hypothesis.

H3: The high level of accountability of government has a positive influenced on citizens' trust in government in Cambodia.

Responsiveness (RS), it refers directly to the accuracy and speed of public sector reaction to citizens' demands (Thomas \& Palfrey, 1996). The public administration responds to public requests quickly and the public administration in Cambodia has to be efficient and provide the quality solutions for public needs. Therefore, the hypothesis will be developed as the following statement.

H4: The high level of responsiveness of government has a positive influenced on citizens' trust in government in Cambodia.

Equity and inclusiveness: In this study, it refers to the assurance of government for all citizens have right to participate the public interest, include all the citizens in member of society, provide all citizens the same opportunity with well-being. It is also important role to provide the citizens 'trust in government in Cambodia. Therefore, the following hypothesis will be investigated the relationship between equity and inclusiveness and the citizens' trust in government in Cambodia.

H5: The high level of equity and inclusiveness of government has a positive influenced on citizens' trust in government in Cambodia.

\section{Research Methodology}

\subsection{Simple Design and Data Collection}

The quantitative data analysis was studied to investigate the characteristics of good governance influenced on the citizens 'trust in Cambodia. The questionnaires are delivered to 400 participants who are to mark the score of each variable; they are citizens who use the public service. This study is the deductive approach that emphasizes the universal law of cause and effect on explanatory framework which assumes a realistic ontology which is that the reality consists of a world of objectively defined the fact (Ali \& Birley, 1999). The research is the modification of theory by using the relevant method to test the hypotheses proposed. The data is collected by designed by 5 levels of the likert scale questions which are categorized from $1=$ strong disagree to $5=$ strong agree. Likert-scale items are useful for gathering respondents' feelings, opinions, attitudes, etc. on any language-related topics (Brown, 2000).

\subsection{Data analysis}

In order to measure the relationship between dependent and independent variable, the Pearson's Bivariate Correlation and Linear Regression will be used to investigate the model of e-service adoption. The reliability will be also tested the consistent of each variable. Cronbach's alpha is a commonly used measure of reliability of a set of two or more construct indicators. Reliability is a measure of internal consistency of the construct indicators(Streiner, 2003).

\section{Result and Discussion}

\subsection{Pearson's Correlations Matrix}

The Pearson correlation coefficient, also known as the product moment correlation coefficient, is represented in a sample by $\mathrm{r}$, while in the population from which the sample was drawn it is represented by $\mathrm{p}$. The coefficient is measured on a scale with no units and can take a value from -1 through 0 to +1 (Sedgwick, 2012). The significance of $\mathrm{P}$ values on graphs, investigators commonly use a "Michelin Guide" scale. *: $\mathrm{P}<0.05$ (significant), $* *$ : $\mathrm{P}<$ 0.01 (highly significant); $* * *: \mathrm{P}<0.001$ (extremely significant) which are generally accepted conventional level with a confidential interval of $95 \%$ (Graphpad, 2000). In this case, the table 2 indicates that all the variables are positive highly significant to the Citizen's Trust (CT). As the result, Trans has mean score 1.82 with $\mathrm{r}=849^{* *} \mathrm{P}$ 
$<0.01$, AC has mean score 1.83 with $\mathrm{r}=828^{* *} \mathrm{P}<0.01$, RES has mean score 1.96 with $\mathrm{r}=865^{* *} \mathrm{P}<0.01$, IE has mean score 1.81 with $\mathrm{r}=930 * * \mathrm{P}<0.01$, and Trust has mean score 1.69 with $\mathrm{r}=934 * * \mathrm{P}<0.01$. This is clearly indicated that all variables have strong relationship with citizen's trust.

Table 2: Pearson's Correlations Matrix

\begin{tabular}{|c|c|c|c|c|c|c|c|c|}
\hline & RL & Trans & $\mathrm{ACC}$ & RES & EI & Trust & $\begin{array}{l}\text { Mean } \\
\text { Score }\end{array}$ & $\begin{array}{c}\text { St. } \\
\text { Deviation }\end{array}$ \\
\hline RL & $\begin{array}{l}1 \\
\text { Sig. }\end{array}$ & & & & & & 1.8480 & .9621 \\
\hline Trans & $\begin{array}{l}.849^{* *} \\
\text { Sig. }\end{array}$ & 1 & & & & & 1.8219 & 1.0669 \\
\hline $\mathrm{AC}$ & $\begin{array}{l}.928^{* *} \\
\text { Sig. }\end{array}$ & $\begin{array}{l}.916^{* *} \\
\text { Sig. }\end{array}$ & 1 & & & & 1.8313 & 1.01011 \\
\hline RES & $\begin{array}{l}.865^{* *} \\
\text { Sig. }\end{array}$ & $\begin{array}{l}.885^{* *} \\
\text { Sig. }\end{array}$ & $\begin{array}{l}.984^{* *} \\
\text { Sig. }\end{array}$ & 1 & & & 1.9635 & .95868 \\
\hline EI & $\begin{array}{l}.930^{* *} \\
\text { Sig. }\end{array}$ & $\begin{array}{l}.878^{* *} \\
\text { Sig. }\end{array}$ & $\begin{array}{l}.950^{* *} \\
\text { Sig. }\end{array}$ & $\begin{array}{l}.929^{* *} \\
\text { Sig. }\end{array}$ & 1 & & 1.8190 & .81209 \\
\hline Trust & $\begin{array}{l}.934^{* *} \\
\text { Sig. }\end{array}$ & $\begin{array}{l}.849^{* *} \\
\text { Sig. }\end{array}$ & $\begin{array}{l}.867^{* *} \\
\text { Sig. }\end{array}$ & $\begin{array}{l}.788^{* *} \\
\text { Sig. }\end{array}$ & $\begin{array}{l}.903^{* *} \\
\text { Sig. }\end{array}$ & $\begin{array}{l}1 \\
\text { Sig. }\end{array}$ & 1.6912 & .74050 \\
\hline
\end{tabular}

\subsection{Structure Equation Model (SEM)}

The SEM of this paper is referred to the independent variable (X) and dependent variable (Y). Linear Regression can analyze only one linkage between independent and dependent variable at a time (Gerbing \& Anderson, 1988). According to this research model, Trans, ACC, Res, and EI are independent variable (IV) and Trust is dependent variable (DV). In this case, Linear Regression is tested to measure the relationship between independent and depend variable. The linear regression between IV (RL, Trans, ACC, Res, and EI) and Citizens 'Trust (DV) is tested. The result of Linear Regression is illustrated as the following tables:

Table 3: It is indicated that $\mathrm{H} 1(\mathrm{RL})$ has measure value as $\beta=-.343, \mathrm{t}=-2.548, \mathrm{P}=.011$ which is greater than the common alpha level 0.05 . This indicates that it is not statistically significant. The H2Transparency (Trans) has measure value as $\beta=.310, \mathrm{t}=3.924, \mathrm{P}=.000<0.01$. The $\mathrm{H} 3$ shows that Accountability (ACC) has measure value as $\beta=.2 .265, \mathrm{t}=11.943, \mathrm{P}=.000<0.01$. The H4 Responsibility (Res) has measure value as $\beta=-2.184, \mathrm{t}=$ $12.800, \mathrm{P}=.000<0.01$, and lastly the $\mathrm{H} 5$ Equity and Inclusiveness $(\mathrm{EI})$ has measure value as $\beta=.826, \mathrm{t}=12.338$, $\mathrm{P}=.000<0.01$. These are indicated that all of hypotheses predicted $(\mathrm{H} 2, \mathrm{H} 3$, and $\mathrm{H} 5)$ are strongly positive influenced on citizens 'trust on government, but H4 (Res) is the highest negative influenced on the citizens 'trust (Trust).

Table 3: Result of Hypotheses Testing

\begin{tabular}{|c|c|c|c|c|c|}
\hline Hypotheses & $\begin{array}{l}\text { Relationship } \\
\text { and DV) }\end{array}$ & Coefficient ( $\beta)$ & T -value & Sig. (P-value) & Support \\
\hline H1 & $\mathrm{RL} \rightarrow$ Trust & -.343 & -2.548 & .011 & Rejected \\
\hline H2 & Trans $\rightarrow$ Trust & .310 & 3.924 & .000 & Confirm \\
\hline H3 & $\mathrm{ACC} \rightarrow$ Trust & 2.265 & 11.943 & .000 & Confirm \\
\hline H4 & Res $\rightarrow$ Trust & -2.184 & -12.800 & .000 & Confirm \\
\hline H5 & $\mathrm{EI} \rightarrow$ Trust & .826 & 12.338 & .000 & Confirm \\
\hline
\end{tabular}

Dependent Variable: Citizens 'Trust 


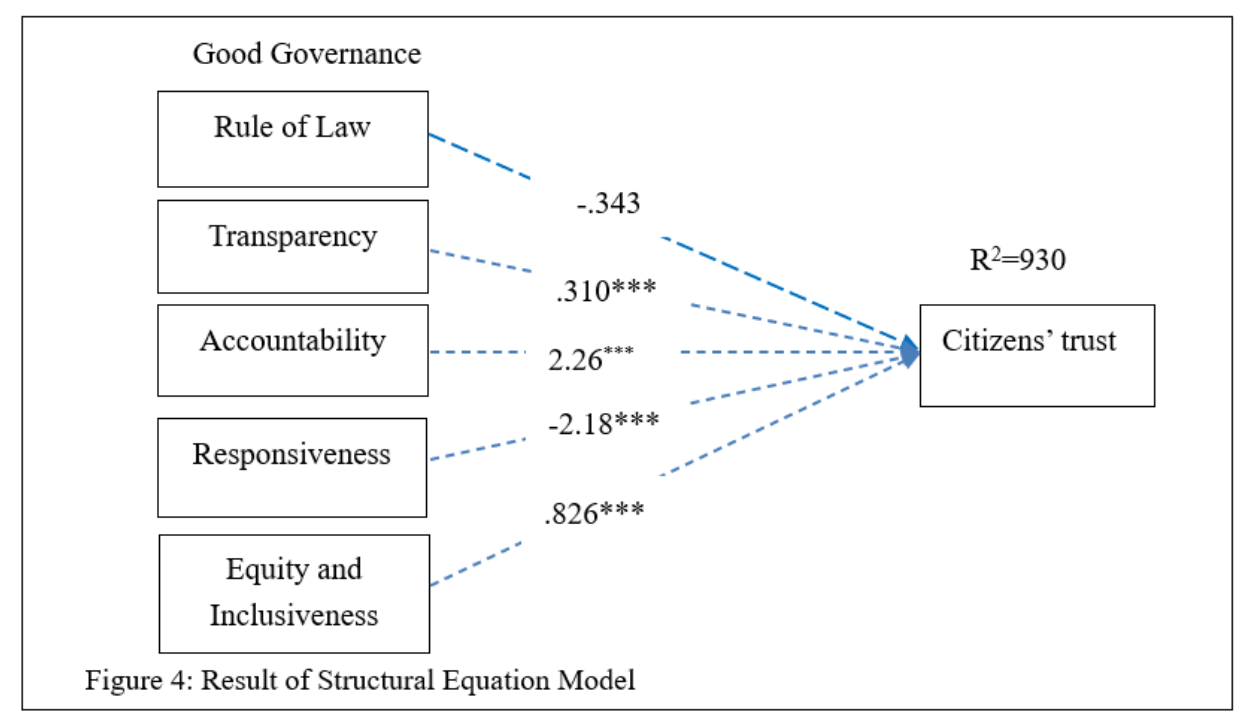

\subsection{Reliability Test}

The research instrument is tested to found out the reliable data for measurement this research model. According to the statistic rule, the majority of individuals correctly reported Cronbach's alpha as the measure of internal consistency reliability, but then opted to conduct data analysis using individual items (Gliem \& Gliem, 2003). The following rules of thumb was provided " $\geq .9$ - Excellent, $\geq .8$ - Good, $\geq .7$ - Acceptable, $\geq .6$ - Questionable, $\geq .5$ - Poor, and $\geq .5$ - Unacceptable" (George \& Mallery, 2003). AS the result, the table 4 is indicated that the value of Alpha for each determinant $(\mathrm{RL}=.973$, Trans $=.977, \mathrm{ACC}=.972$, Res. $=.977, \mathrm{EI}=.975$, and Trust $=.981)$ and table 6 is indicated that the total of three variable value of Alpha is 983. It is shown the excellent reliability and the data collected by questionnaire are believable of $98,3 \%$ of participants 'responses.

\begin{tabular}{lll}
\hline \multicolumn{2}{l}{ Table 4 Reliability for each Variable } \\
\hline Construct & Items & Cronbach's Alpha \\
\hline RL & 5 & .973 \\
Trans & 4 & .977 \\
ACC & 4 & .972 \\
Res & 5 & .977 \\
EI & 5 & .975 \\
Trust & 6 & 981 \\
\hline
\end{tabular}

Table 5: Reliability total of variable Cronbach's Alpha|Cronbach's Alpha Standardized items N of Items .980 .983 6

\section{Conclusion, Recommendation and future research}

In conclusion, regarding to this study, it is found that the citizens' trust in government in Cambodia has strong relationship with rule of law, accountability, responsibility, and equity and inclusiveness which are illustrated with Pearson's correlation in table 2.

Linear Regression testing in table 3 is indicated that all predicted dependent variables (accountability, responsibility, and equity and inclusiveness) are confirmed with citizens' trust. It means that they are significant. The rule of law is not significant with citizens' trust.

During survey, it was felt that citizens' trust in government for the case of Cambodia is flawed. To address this urgent need improved the citizens' trust in government is compiled through observations, group discussions, newspapers and interview with citizens. To improve the implementation of Cambodian government, the government or top management leaders have the important roles to improve all of the determinant factors which have been found in this study as the following suggestions.

1. Rule of law is important roles for government in Cambodia to deliver the public service and make the citizens' trust. For example, the top leaders set regulations or actions plans to promote the trust if the government services are fairness and respect the law for all citizens. In this model, rule of law are low respect by law practitioner regarding to citizens' respondents.

2. Transparency is also the main problems for Cambodia situation, it lacks of sharing information to 
participants before policy making. Regarding to my opinion, the top government leader should pay attention, I expect that the citizens have enough information, they will trust in government for public services.

3. Accountability is the reliable work of government to use power fairly and independently for citizen. Related to this result, the mean score is law level, it means that it is strongly disagree. The government should strengthen the independent of their roles in serving the public service.

4. Responsiveness is directly to the accuracy and speed of public sector reaction to citizens' demands. This factor also low score which is indicated by the result of citizens' respondents. Therefore, the government needs to improve behavior to response the citizen quickly as soon as possible in order to make citizens' trust in government.

5. Equity and inclusiveness refers to the assurance of government for all citizens have right to participate the public interest, include all the citizens in member of society, provide all citizens the same opportunity with well-being. The result is indicated that the score responded by the citizens is low level of government's practitioner. To make the citizens 'trust government should give all citizens to participate the public interest include all the citizens in member of society.

The limitation of future research, these factors of trust in government as the determinant of rule of law (RL), Transparency, Accountability, Responsibility and Equity and Inclusiveness may investigate again to predict the variable factors of citizens' trust because these variables are just the contribution idea only, so that it maybe not sufficient to synthesize the real proof for citizens' trust. In contrary, the next scholars may also develop this model by adding or reducing the necessary determinants which she or he think that it is better to improve the citizens' trust for Cambodia situation. Briefly, for future research for next scholars, they can propose this model again or add some related variables to investigate again as the model for their distribution conceptual framework, because it maybe will be change the behaviour of government and citizens.

\section{Acknowledgement}

This research is encouraged by Professor Liu Qijun, the College of Public Administration (HUST), it is sponsored by Chinese Government Scholarship. It would not be achieved if it has not his comment and support. On the other hand, it is also participated with the respondents as citizens who are served by Cambodian government.

\section{References}

Ali, H., \& Birley, S. (1999). Integrating deductive and inductive approaches in a study of new ventures and customer perceived risk. Qualitative market research: an international journal, 2(2), 103-110.

Ananny, M., \& Crawford, K. (2018). Seeing without knowing: Limitations of the transparency ideal and its application to algorithmic accountability. New Media \& Society, 20(3), 973-989.

Babovic, M., \& Vukovic, D. (2014). Social accountability in Cambodia. LSE JRSP Paper, 19.

Bentham, J., James, M., Blamires, C. P., \& Pease-Watkin, C. (1999). Political tactics.

Blind, P. K. (2007). Building trust in government in the twenty-first century: Review of literature and emerging issues. Paper presented at the 7th Global Forum on Reinventing Government Building Trust in Government.

Bourne, L. (2014). The six functions of governance.

Brown, J. D. (2000). What issues affect Likert-scale questionnaire formats. Shiken: JALT Testing \& Evaluation SIG Newsletter, 4(1).

Burman, B., Albinsson, P. A., \& Hyatt, E. (2016). One night or many? Effects of amenity charge transparency on consumer reaction. Journal of Hospitality Marketing \& Management, 25(8), 1010-1033.

Cadbury, A. (2002). Corporate governance and chairmanship: A personal view: Oxford University Press on Demand.

Caillier, J. (2010). Citizen trust, political corruption, and voting behavior: Connecting the dots. Politics \& Policy, $38(5), 1015-1035$.

Cambodia, R. G. o. (2010). Good Governance in Cambodia. Phnom Penh: Ministry of Interoir of Cambodia.

Doornbos, M. (1995). State Formation Processes under External Supervision: Reflections on Good Governance. Aid and political conditionality, 377-391.

Fard, H. D., \& Rostamy, A. A. A. (2007). Promoting public trust in public organizations: Explaining the role of public accountability. Public Organization Review, 7(4), 331-344.

Fukuyama, F. (2013). What is governance? Governance, 26(3), 347-368.

George, D., \& Mallery, P. (2003). SPSS for Windows Step by Step: A Simple Guide and Reference Fourth Edition (11.0 update): Answers to Selected Exercises: Boston, MA: Allyn \& Bacon.

Gerbing, D. W., \& Anderson, J. C. (1988). An updated paradigm for scale development incorporating unidimensionality and its assessment. Journal of marketing research, 186-192.

Gliem, J. A., \& Gliem, R. R. (2003). Calculating, interpreting, and reporting Cronbach's alpha reliability coefficient for Likert-type scales. 
Graphpad. (2000). Intuitive Biostatistics: Interpreting Nonsignificant P values. Copyright (C) 1995 by Oxford University Press Inc.

Gutmann, J., \& Voigt, S. (2018). The rule of law: Measurement and deep roots. European Journal of Political Economy, 54, 68-82.

Hardin, R. (1999). Do we want trust in government. Democracy and trust, 22-41.

Hyndman, N., \& McConville, D. (2018). Trust and accountability in UK charities: Exploring the virtuous circle. The British Accounting Review, 50(2), 227-237.

Imenda, S. (2014). Is there a conceptual difference between theoretical and conceptual frameworks? Journal of Social Sciences, 38(2), 185-195.

Joshua. (2011). Difference Between Government and Governance: DB Difference Between.net.

Keping, Y. (2018). Governance and Good Governance: A New Framework for Political Analysis. Fudan Journal of the Humanities and Social Sciences, 11(1), 1-8.

Kevreaksmey, P., Bing, W., Ratanak, N., \& Keosambath, P. (2015). A Research on Good Governance and Poverty Reduction in Cambodia.

Mayer, R. C., Davis, J. H., \& Schoorman, F. D. (1995). An integrative model of organizational trust. Academy of management review, 20(3), 709-734.

Nanda, V. P. (2006). The "good governance" concept revisited. The ANNALS of the American academy of political and social science, 603(1), 269-283.

Punyaratabandhu, S. (2004). Commitment to good governance, development and poverty reduction: Methodological issues in the evaluation of progress at the national and local levels: UN.

Rose-Ackerman, S. (2001). Trust, honesty and corruption: Reflection on the state-building process. European Journal of Sociology/Archives Européennes de Sociologie, 42(3), 526-570.

Salminen, A., \& Ikola-Norrbacka, R. (2010). Trust, good governance and unethical actions in Finnish public administration. International Journal of Public Sector Management, 23(7), 647-668.

Sedgwick, P. (2012). Pearson's correlation coefficient. BMJ: British Medical Journal (Online), 345.

Sloan, M. F. (2009). The effects of nonprofit accountability ratings on donor behavior. Nonprofit and voluntary sector quarterly, 38(2), 220-236.

Streiner, D. L. (2003). Being inconsistent about consistency: When coefficient alpha does and doesn't matter. Journal of personality assessment, 80(3), 217-222.

Thomas, P., \& Palfrey, C. (1996). Evaluation: stakeholder - focused criteria. Social Policy \& Administration, $30(2), 125-142$

Tsang, S., Burnett, M., Hills, P., \& Welford, R. (2009). Trust, public participation and environmental governance in Hong Kong. Environmental Policy and Governance, 19(2), 99-114. 


\section{APPENDIX 1 - QUESTIONNAIRE ITEM}

Good governance

H1: Rule of law

1. I think that the laws are applicable to all citizens equally.

2. I think that the laws are followed by public interest.

3. I think that the law makers are the representative of the citizens.

4. I think that the policies are made according to society demand.

5. I think that human right was protected by government

H2: Transparency

1. I think that decisions of government are clarified by law and regulation.

2. I see that the administration officer provide proper information before he makes decision for serving the citizens.

3. I see that the information of government project is enough and easy to understand by citizens

4. I see that the decision of government project is opening for all citizens.

H3: Accountability

1. Judiciary is independent

2. Police force is incorruptible

3. Police force is reliable in their working

4. Judiciary and police force work freely and independently

H4: Responsiveness

1. Language in administration processes or decision is user friendly

2. There is proper procedure to contact administration for problem

3. Affairs are handheld timely

4. Government show involvement toward an issue

5. Issues are prioritized according to need and emergence

H5: Equity and inclusiveness

1. The government ensures that all the member of citizen have right to comment for public service.

2. I see that the government consider the citizens to be the really member of society.

3. I see that the most vulnerable, have opportunities to improve or maintain their well-being by government.

4. I see that the fairness implies all personal or socio-economic circumstances, such as gender, ethnic origin, or family background

5. I see that all government ensure all the citizens have right to get justice with political tendency.

H6: citizens' trust (service quality, information, partisan, promise of politician)

1. I trust the quality of public service because the government is responsive in term of policy making (trust of service quality)

2. I trust the quality of public service because behavior of public service provider is friendly and problem solving (trust of service quality)

3. I trust satisfy the information about public service provided by government (Information)

4. Think that an affiliation with a party (Partisan) in government increase trust and satisfaction with the quality of service (Partisan)

5. I trust in government because the public service providers are honest and fair (promise)

6. I trust in government because the promise made by politicians are kept or fulfilled (promise) 